\title{
DOSSIÊ CIDADE E NATUREZA
}

\section{THEMATIC SECTION CITY AND NATURE}

v. 8, n. 2 [13]

mai/ago (2016)

Dossiê Cidade e Natureza
Janes Jorge

Universidade Federal de São Paulo jjunifesp@gmail.com

Carmen Lúcia Soares Universidade Estadual de Campinas soares.carmenlucia@gmail.com

André Dalben Universidade Estadual de Londrina andredalben@uel.br

Compreender a relação entre as cidades e a natureza foi tarefa imprescindível para quem se dedicou a pensar as questões urbanas. Quase sempre isso ocorreu em razão de necessidades práticas e imediatas, como garantir seu abastecimento de água, comida e energia; a dispersão das águas servidas e de outros resíduos; a defesa contra inimigos próximos ou distantes para se construir vias de comunicação ou mesmo para impulsionar o desenvolvimento econômico. Mesmo em casos extremos, quando se procurou descolar a cidade de seu lugar de nascimento, essa relação estava presente, ainda que pela negação. Os que foram mais além das necessidades imediatas, deram atenção ainda maior ao modo como as relações humanas e o mundo natural interagiam no espaço urbano, e, nunca deixaram de ver as cidades como um caminho possível para a concretização da utopia de uma sociedade livre, plena de vida, alegria, inteligência e justiça.

A cada época, a natureza e as cidades foram redescobertas por novas sensações e emoções, foram apropriadas de diferentes formas para novos usos, foram constantemente reinterpretadas por inúmeros discursos e por novos saberes. A descoberta das possibilidades de divertimento na natureza, por exemplo, esteve associada com um peso cada vez maior que a cultura conquistou sobre as sensações imediatas, o que tornaria possível a reivindicação de uma natureza idealizada para o usufruto dos moradores urbanos em seus momentos de ócio. 
Note-se que em nosso tempo essa relação ficou ainda mais complexa, pois, desde fins do século $X X$, a humanidade se encontra diante de uma grave crise ambiental. Dessa forma, pensar a relação da cidade com o mundo natural se tornou ainda mais complexo, pois é preciso considerar fatores como as mudanças climáticas, por exemplo. Não é exagero afirmar que a superação da crise ambiental contemporânea passa pelas cidades, lugar aonde vive a maior parte da população mundial, pois, ao processarem quantidades formidáveis de trabalho, recursos naturais, energia e gerarem todo tipo de resíduos, causam forte impacto nos sistemas naturais que suportam a vida do planeta, o que atinge os seres humanos nas cidades ou fora delas.

Foi pensando nessa multiplicidade de reflexões, resultantes das relações históricas entre os processos de urbanização, o meio ambiente e as diferentes representações de natureza consolidadas por nossas sociedades, que organizamos o Seminário Cidade e Natureza, realizado em 22 de maio de 2015 na Universidade Estadual de Campinas. O evento reuniu professores e estudantes de pós-graduação de diversas áreas do conhecimento que se dedicam ao estudo das inter-relações entre os seres humanos e a natureza a partir de uma perspectiva histórica e que atuam junto ao Grupo de Trabalho em História Ambiental, da Associação Nacional de História - Seção São Paulo (ANPUH-SP). O presente Dossiê Cidade e Natureza foi organizado como forma de registro dos trabalhos apresentados no Seminário Cidade e Natureza e como continuidade das ações do Grupo de Trabalho em História Ambiental no sentido de aproximar pesquisadores e suas respectivas produções, favorecendo, assim, a promoção contínua de interações acadêmicas, diálogos interdisciplinares, trocas de experiências e divulgação científica.

(c) Urbana: Rev. Eletrônica Cent. Interdiscip. Estud. Cid. 